\title{
Release of Penicillinase by Bacillus licheniformis
}

\author{
By J. O. LAMPEN* \\ National Institute for Medical Research, Mill Hill, London, N.W.7
}

(Accepted for publication 9 March 1967 )

\begin{abstract}
SUMMARY
Organisms (logarithmic growth phase) of Bacillus licheniformis strain $749 / \mathrm{C}$ when washed and resuspended in buffer ceased to produce penicillinase but continued to release their cell-bound enzyme as typical exopenicillinase. In the first I-2 hr, 15-30\% of the bound enzyme was liberated; the process then became very slow. Liberation was dependent upon temperature and pH value; it was not inhibited by chloramphenicol. Release was apparently not a result of membrane damage, since there was no leakage of intracellular $\alpha$-glucosidase. Lysis of the bacilli decreased sharply the rate of release of exoenzyme.

Membrane preparations active in releasing penicillinase were obtained by lysing the bacilli with lysozyme in the absence of added $\mathrm{Mg}^{2+}$ and subsequently adding $0.05 \mathrm{M}-\mathrm{MgSO}_{4}$ to prevent dispersal of the membrane segments. The liberation of penicillinase by this fraction had the same general enzymic properties as had the process with intact bacilli. Disruption of the membranes also eliminated most of the penicillinase-releasing activity. The importance of membrane structure in the liberation process is discussed.
\end{abstract}

\section{INTRODUCTION}

In the preceding paper (Lampen, 1967) evidence is presented that the cell-bound penicillinase of Bacillus licheniformis strain $749 / \mathrm{C}$ is covalently linked to the exterior of the cell membrane by a peptide chain which can be cleaved by trypsin. This material appears to be a precursor of the natural exopenicillinase (Pollock, 196 $a, b$; Collins, 1964; Lampen, 1965). Although one may argue that the crucial stages in the production of an external or extracellular enzyme have been completed by the time a bound enzyme can be detected on the outer side of the membrane, the phenomenon of liberation may provide information from which one can infer characteristics of the formation of the enzyme.

Pollock (I96r $a$ ) was able to separate to a large extent the liberation of penicillinase from its net production. He added a limiting amount of a metabolizable inducer (benzylpenicillin) to a growing culture of Bacillus licheniformis strain 6346. Release of enzyme into the medium continued after the induced formation of new enzyme had declined sharply. Liberation appeared to require an enzymic reaction (Pollock, $196 \mathrm{r} b$ ), since it was temperature-dependent and did not occur at $\mathrm{pH}$ values less than 6.0 , and the enzyme was not eluted from the bacilli by high concentrations of salts. Chloramphenicol at high concentrations produced a partial inhibition of exoenzyme release. In an attempt to obtain a simplified system, Kushner \& Pollock (I96I) investigated

\footnotetext{
* Present address: Institute of Microbiology, Rutgers, The State University, New Brunswick, New Jersey, U.S.A.
} 
the liberation of penicillinase by 'disrupted spheroplasts' of $B$. licheniformis 6346 . To produce these forms, bacilli were treated with lysozyme in the presence of $0.05 \mathrm{M}$ $\mathrm{MgSO}_{4}+0.3 \mathrm{M}$-sucrose and were subsequently centrifuged and resuspended in $0.05 \mathrm{M}-\mathrm{Mg}^{2+}$ without osmotic support. The residues still contained as much as $98 \%$ of the original cell-bound penicillinase, but less than $5 \%$ of the (normally $100 \%$ cellbound) $\alpha$-glucosidase. Release of penicillinase from these particles was inhibited by $0.05 \mathrm{M}-\mathrm{Mg}^{2+}$ and by $p$-chloromercuribenzoate. Trypsin or sodium deoxycholate rapidly liberated the enzyme in a form not sedimentable in $10 \mathrm{~min}$. at $20,000 \mathrm{~g}$. Once it was known that the bound penicillinase of $B$. licheniformis strain $749 / \mathrm{C}$ is covalently linked to the cell membrane (Lampen, 1967), an attempt was made to extend the observations with $B$. licheniformis 6346 to the more active and stable strain $749 / \mathrm{C}$. Initial studies showed that spheroplast formation was slow under the conditions previously used and that lysis was incomplete. An investigation of the liberation of penicillinase from strain 749/C was therefore undertaken. A summary of these results has been previously presented (Lampen, 1965).

\section{METHODS}

The preceding paper (Lampen, 1967) describes the procedures for maintaining spore stocks of Bacillus licheniformis $749 / \mathrm{C}$, for preparing logarithmic-phase bacilli and the techniques for starch gel electrophoresis and detection and estimation of bound and free penicillinase. Formation of $\alpha$-glucosidase was induced by adding maltose at $2 \mathrm{mg}$. $/ \mathrm{ml}$. to cultures whose populations had reached the equivalent of $0 . \mathrm{I} \mathrm{mg}$. dry wt bacilli $/ \mathrm{ml}$. $\alpha$-Glucosidase activity was measured by the rate of hydrolysis of $p$-nitrophenyl- $\alpha$-D-glucoside at $30^{\circ}$ and $\mathrm{pH} 7 \cdot 0$ (Pollock, 1961 $a$ ) and expressed as $\mu$ moles $p$-nitrophenol formed/hr. For the determination of total $\alpha$-glucosidase activity, bacilli were shaken at $35^{\circ}$ in stoppered tubes for 20 min., with 2 or 3 drops of butanol which was afterwards removed by a stream of air.

\section{RESULTS}

\section{Release of penicillinase by washed organisms}

The system for liberation of the cell-bound enzyme from strain Bacillus licheniformis $749 / \mathrm{C}$ resembles that of $B$. licheniformis strain 6346 in its dependence on temperature and $\mathrm{pH}$ value (Table $\mathrm{I}$ ), and thus also appears to be enzymic. At $\mathrm{pH} 5.0$ the amount of free enzyme produced was slight, although a considerable amount of particle-bound enzyme was released, possibly as a result of cell lysis. An added energy source was not required for formation of free enzyme. In contrast to the results with strain 6346 chloramphenicol even at $100 \mu \mathrm{g}$. $/ \mathrm{ml}$. did not inhibit release of enzyme by strain $749 / \mathrm{c}$. The reason for this difference is not clear. However, in the present studies formation of new enzyme was arrested by removal of the nitrogen source, whereas with strain 6346 (Pollock, 1961 $a$ ) the bacilli were in a complete growth medium but with their supply of inducer exhausted. A small net synthesis of penicillinase (and perhaps of the system for its release) was still taking place. Inhibition of these synthetic processes by chloramphenicol may have produced the observed partial decrease in the net amount liberated. There was no net synthesis of penicillinase by bacilli of strain $749 / \mathrm{c}$ placed in a nitrogen-free medium; under comparable conditions yeast protoplasts formed invertase for several hours at a rapid rate which was not increased by adding a mixture 
of amino acids (Lampen, 1965). This difference may reflect the relatively large amino acid pool in yeast (Halvorson, Fry \& Schwemmin, 1955).

The release of penicillinase was relatively rapid at first; $15-30 \%$ of the total bound enzyme was generally liberated in the first $0.5-2 \mathrm{hr}$ (typical results are given in Tables I and 2); later the rate decreased to a few $\% / \mathrm{hr}$. Release was not the result of membrane damage or lysis during incubation in the absence of growth or protein synthesis. Most of the active material released had the mobility of the exoenzyme and was not bound to membrane fragments. No leakage of the cell-bound $\alpha$-glucosidase was detected during a period when about $20 \%$ of the bound penicillinase was liberated (Table 2). Pollock ( $196 \mathrm{I} a$ ) showed that leakage of this enzyme is an excellent indication of damage to the cell membrane.

Table I. Release of penicillinase by washed bacilli of Bacillus licheniformis strain $749 / 6$

Log-phase organisms were washed in $0.01 \mathrm{M}$-tris buffer ( $\mathrm{pH} 7.5)$ and resuspended in the same buffer. Each incubation mixture contained (per ml.) $1.0 \mathrm{mg}$. (dry wt equiv.) bacilli, $50 \mu \mathrm{g}$. chloramphenicol and other supplements as indicated. After incubation for $2 \mathrm{hr}$, samples were frozen directly for measurement of total activity or centrifuged for Io min. at $20,000 \mathrm{~g}$ and the supernatant fluids frozen for subsequent assay and starch gel electrophoresis.

\begin{tabular}{|c|c|c|c|c|c|}
\hline \multirow[b]{3}{*}{ Additions } & \multicolumn{5}{|c|}{ Penicillinase in supernatant fluid } \\
\hline & \multirow[b]{2}{*}{$\begin{array}{l}\text { Temp. } \\
\left({ }^{\circ} \mathrm{C} .\right)\end{array}$} & \multirow[b]{2}{*}{$\begin{array}{c}\text { Total } \\
\text { penicillinase } \\
\text { units/ml. }\end{array}$} & \multirow[b]{2}{*}{$\begin{array}{c}\text { Total } \\
\text { units } / \mathrm{ml} \text {. }\end{array}$} & \multicolumn{2}{|c|}{ Free enzyme* } \\
\hline & & & & $\begin{array}{l}\% \text { of } \\
\text { total }\end{array}$ & units/ml. \\
\hline - & - & $\begin{array}{c}4530 \\
\text { (o time) }\end{array}$ & - & - & - \\
\hline 一 & o & - & 480 & 70 & 340 \\
\hline - & 30 & 4770 & 1660 & 80 & 1330 \\
\hline Chloramphenicol omitted & 30 & 4600 & 1650 & 80 & 1320 \\
\hline $\mathrm{Na}$ acetate buffer, $(0.05 \mathrm{M}, \mathrm{pH} 5.0)$ & 30 & 4460 & 780 & 25 & 200 \\
\hline Glucose, $0.5 \% \dagger$ & 30 & 4700 & I 580 & 50 & 790 \\
\hline
\end{tabular}

* Has the electrophoretic mobility of natural exopenicillinase. $\dagger$ During incubation the $\mathrm{pH}$ fell to $6 \cdot 5$.

\section{Nature of disrupted spheroplasts}

When Bacillus licheniformis 749/C was treated with lysozyme in the presence of $0.05 \mathrm{M}-\mathrm{Mg}^{2+}+0.3 \mathrm{M}$-sucrose and subsequently suspended in a medium lacking osmotic support, the residues contained more than $90 \%$ of the original cell-bound penicillinase (Table 3). This was consistent with the observations of Kushner \& Pollock (I96I) who used $B$. licheniformis strain 6346 . These residues consisted predominantly of rodshaped Gram-variable forms which lysed only when the $0.05 \mathrm{M}-\mathrm{Mg}^{2+}$ was also removed. They contained $70-80 \%$ of the protein and nucleotide material of the original bacilli. When $\mathrm{Mg}^{2+}$ was not present during treatment with lysozyme, most of the protein and polynucleotide was released upon removal of the osmotic support, along with large quantities of penicillinase, most of which was bound to membrane fragments. It is clear that $0.05 \mathrm{M}-\mathrm{Mg}^{2+}$ protected the cell wall against the action of lysozyme to a degree sufficient to prevent the production of true spheroplasts. The criterion of Kushner \& Pollock (196r) for liberated enzyme (not sedimented in Iomin. at $20,000 \mathrm{~g}$ ) would not 
distinguish the true exo-form from enzyme bound to small fragments of membrane. It is suggested, therefore, that the protective effect of $\mathbf{M g}^{2+}$ and release of penicillinase by sodium deoxycholate which Kushner \& Pollock observed reflected the protection and the fragmentation, respectively, of the spheroplasts, rather than direct action on the cell-bound enzyme.

Table 2. Release of penicillinase without leakage of $\beta$-glucosidase from washed Bacillus licheniformis 749/C

The experimental conditions were those given in Table I, except that $4.0 \mathrm{mg}$. (dry wt equiv.) of bacilli grown in the presence of maltose to induce formation of $\alpha$-glucosidase were present per $\mathrm{ml}$. Incubation at $30^{\circ}$.

\begin{tabular}{|c|c|c|c|c|}
\hline \multirow[b]{2}{*}{ Time (hr) } & \multicolumn{2}{|c|}{ Penicillinase (units $/ \mathrm{ml}$.) } & \multicolumn{2}{|c|}{$\alpha$-Glucosidase (units/ml.) } \\
\hline & Total & Released* & Total & Released \\
\hline 0 & 26,000 & 200 & $18 \cdot 2$ & $<0.2$ \\
\hline 0.5 & 24,300 & 1400 & - & - \\
\hline 2 & 24,000 & 3000 & I8·I & $<0.2$ \\
\hline 3 & 25,100 & 3900 & - & - \\
\hline 4 & 23,000 & 4400 & $18 \cdot 7$ & $<0.2$ \\
\hline
\end{tabular}

* More than $90 \%$ of the released activity had the electrophoretic mobility of exopenicillinase.

\section{Table 3. Protection by $0.05 \mathrm{M}-\mathrm{MgSO}_{4}$, against the disintegration of Bacillus licheniformis 749/c organisms during treatment with lysozyme}

Log-phase bacilli ( $24.4 \mathrm{mg}$. dry wt equiv.) containing 80,000 units of penicillinase, $14 \mathrm{mg}$. protein, and 160 units of total nucleotide (based on $E_{\mathbf{2 6 0}}$ value of a lysed preparation) were added to $60 \mathrm{ml}$. of $0.01 \mathrm{M}$-phosphate buffer $(\mathrm{pH} \mathrm{7.5)}+0.3 \mathrm{M}$-sucrose. Lysozyme (100 $\mu \mathrm{g}$. $/ \mathrm{ml}$.) was added at zero time and the mixtures shaken gently for 2 or $5 \mathrm{~min}$. at $30^{\circ}$. The suspensions were quickly cooled and centrifuged at $15,000 \mathrm{~g}$ for $15 \mathrm{~min}$. The supernatant fluids represent the material released during formation of spheroplasts. The pellet was suspended in $0.0 \mathrm{I} \mathrm{M}-$ phosphate buffer $\left( \pm \mathrm{Mg}^{2+}\right)$ at $0^{\circ}$, homogenized for $2 \mathrm{~min}$. in a Potter-Elvehjem type of tube, and centrifuged $10 \mathrm{~min}$. at $20,000 \mathrm{~g}$. This supernatant fluid contained the material released by lysis of the spheroplasts. The residues were finally extracted by suspending them in $0.01 \mathrm{M}$-phosphate buffer (without $\mathrm{Mg}^{+2}$ ) at $30^{\circ}$ for $10 \mathrm{~min}$. Ribonuclease (10 $\mu \mathrm{g} . / \mathrm{ml}$ ) and deoxyribonuclease $(5 \mu \mathrm{g} . / \mathrm{ml}$.) were added to decrease the viscosity. The final sediment was removed by centrifugation at $3000 \mathrm{~g}$ for $10 \mathrm{~min}$.

\begin{tabular}{|c|c|c|c|c|}
\hline \multirow[b]{2}{*}{ Procedure } & \multirow[b]{2}{*}{ Cell fraction } & \multicolumn{2}{|c|}{$\begin{array}{c}\% \text { of total fraction released during } \\
\text { indicated procedure } \\
\text { No } \mathrm{Mg}^{2+}\end{array}$} & \multirow{2}{*}{$\begin{array}{l}0.05 \mathrm{M}-\mathrm{Mg}^{2+} \\
5 \mathrm{~min} .\end{array}$} \\
\hline & & $2 \mathrm{~min}$. & $5 \mathrm{~min}$. & \\
\hline $\begin{array}{l}\text { Formation of } \\
\text { spheroplasts }\end{array}$ & $\begin{array}{l}\text { Penicillinase } \\
\text { Nucleotide } \\
\text { Protein }\end{array}$ & $\begin{array}{r}5 \\
13 \\
13\end{array}$ & $\begin{array}{l}42(B)^{*} \\
18 \\
18\end{array}$ & $\begin{array}{l}4(F)^{*} \\
3 \\
5\end{array}$ \\
\hline $\begin{array}{l}\text { Lysis of } \\
\text { spheroplasts }\end{array}$ & $\begin{array}{l}\text { Penicillinase } \\
\text { Nucleotide } \\
\text { Protein }\end{array}$ & $\begin{array}{l}38 \\
39 \\
67\end{array}$ & $\begin{array}{l}25 \text { (B) } \\
38 \\
55\end{array}$ & $\begin{array}{l}4(F) \\
14 \\
25\end{array}$ \\
\hline $\begin{array}{l}\text { Extraction of } \\
\text { spheroplast }\end{array}$ & Penicillinase & $65 t$ & $10 \dagger$ & $\begin{array}{c}68 \\
(4 B: I F) \ddagger\end{array}$ \\
\hline residues & Nucleotide & 25 & 20 & 74 \\
\hline
\end{tabular}




\section{Membrane structure and release of penicillinase}

Bacillus licheniformis 749/C was suspended in the usual test mixture for determining release of bound penicillinase (as Table I; no $\mathrm{Mg}^{2+}$ ) and was lysed with lysozyme. Under these conditions (no added $\mathrm{Mg}^{2+}$ or osmotic support) the membrane disintegrated and much of the membrane-bound penicillinase did not sediment in 10 min. at $20,000 \mathrm{~g}$. The liberation of free enzyme was sharply decreased following lysis,

\section{Table 4. Importance of membrane structure for release of penicillinase}

Preparations from Bacillus licheniformis $749 / \mathrm{c}$. The penicillinase preparations were added at zero time to $0.0 \mathrm{I} \mathrm{M}$-tris buffer ( $\mathrm{pH} \mathrm{7.5)} \mathrm{containing} 50 \mu \mathrm{g}$. chloramphenicol $/ \mathrm{ml}$. and were incubated at $30^{\circ}$. At the stated intervals samples were frozen directly or were centrifuged at $20,000 \mathrm{~g}$ for $10 \mathrm{~min}$. and the supernatant fluid frozen until subsequent assay and starch gel electrophoresis. Membrane fractions were prepared as described in the text.

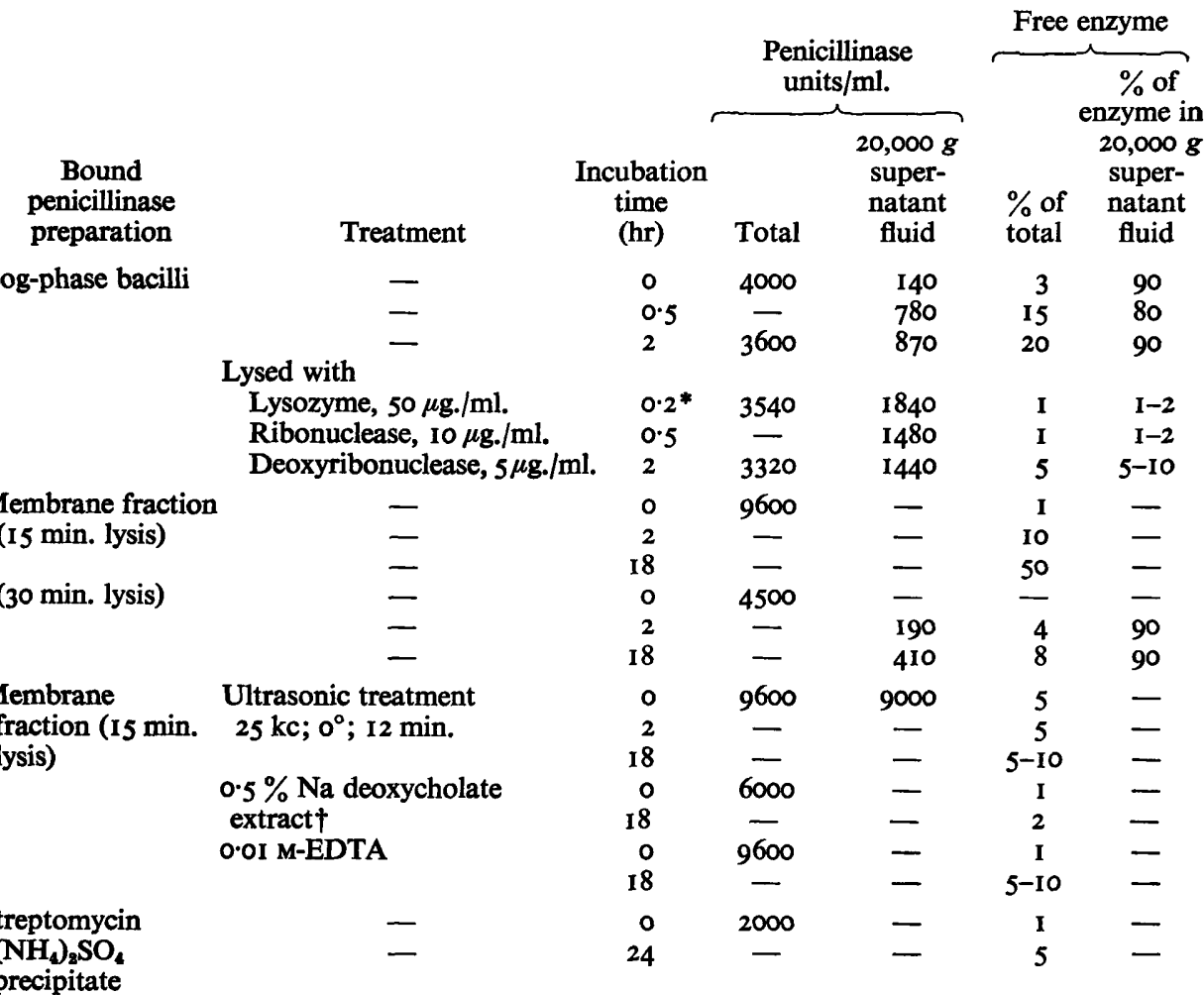

* Lysis essentially complete in ro min.

$\dagger$ This fraction did not prevent release of free enzyme by the membrane fraction (I $5 \mathrm{~min}$. lysis) when present at a ratio of 2: I (based on total units of penicillinase).

despite the fact that the bound enzyme was now free from the bacilli and susceptible to the action of any intracellular proteinases which could release penicillinase from its membrane-bound form (Lampen, 1967). Membrane fractions with moderate activity in releasing penicillinase were obtained, however, when disintegration of the membrane was prevented. Soon after lysis was complete, $0.0 \mathrm{I}-0.05 \mathrm{M}-\mathrm{Mg}^{2+}$ was added and 
the fraction washed with $\mathrm{Mg}^{2+}$ in tris buffer to free it from the added enzymes and cytoplasmic materials. As shown in Table 4, lysis occurred within Io min. Addition of $\mathrm{Mg}^{2+}$ at $15 \mathrm{~min}$. yielded an active preparation. When lysis was allowed to continue for $30 \mathrm{~min}$. the resulting membrane material had a very low penicillinase-releasing activity. In the procedure chosen for subsequent work, $\mathrm{MgSO}_{4}$ was added at $15 \mathrm{~min}$., the mixture held for $10 \mathrm{~min}$. at $0^{\circ}$ and then centrifuged for $10 \mathrm{~min}$. at $5000 \mathrm{~g}$. The sediment was washed by suspension and centrifugation in $0.01 \mathrm{M}$-tris buffer $(\mathrm{pH} 7.5)$ containing $0.05 \mathrm{M}-\mathrm{Mg}^{2+}$, and then in buffer without $\mathrm{Mg}^{2+}$. The final material was essentially free from intact bacilli.

\section{Table 5. Characteristics of penicillinase release by membrane fraction}

Preparations from Bacillus licheniformis $749 / \mathrm{C}$. Membrane fraction was prepared as described in the text. Each incubation mixture contained (per ml.) the membrane fraction from $3.6 \mathrm{mg}$. (dry wt equiv.) of bacilli, $50 \mu \mathrm{g}$. chloramphenicol and other supplements as indicated, in $0.0 \mathrm{I}$ M-tris buffer $\left(\mathrm{pH} \mathrm{7.5)}\right.$. After 0,2 or $18 \mathrm{hr}$ at $30^{\circ}$, samples were frozen directly or centrifuged for $10 \mathrm{~min}$. at $20,000 \mathrm{~g}$. The supernatant fluids were frozen until estimation of penicillinase and starch gel electrophoresis was carried out.

\begin{tabular}{|c|c|c|c|c|c|}
\hline \multirow[b]{3}{*}{ Addition } & & & \multicolumn{3}{|c|}{ Released penicillinase* } \\
\hline & \multicolumn{2}{|l|}{$\begin{array}{c}\text { Incubation } \\
\text { time }\end{array}$} & \multirow{2}{*}{$\begin{array}{c}\text { Total } \\
\text { enzyme } \\
\text { units } / \mathrm{ml} \text {. }\end{array}$} & \multicolumn{2}{|c|}{ Free enzyme } \\
\hline & (hr) & Temp. & & $\%$ & units $/ \mathrm{ml}$. \\
\hline - & 0 & - & 200 & - & - \\
\hline - & 2 & $0^{\circ}$ & 370 & - & - \\
\hline - & 18 & $0^{\circ}$ & 760 & 30 & 230 \\
\hline - & 2 & & 1220 & 75 & 915 \\
\hline 一 & 18 & & 2520 & 75 & I 890 \\
\hline $\mathrm{MgSO}_{4}, 0.05 \mathrm{M}$ & 2 & $30^{\circ}$ & 1160 & 80 & 930 \\
\hline & 18 & & 3620 & 80 & 2900 \\
\hline $\mathrm{Na}$ acetate buffer, $0.05 \mathrm{M}, \mathrm{pH} 5.0$ & 2 & & 460 & 60 & 280 \\
\hline - & I 8 & & 920 & 50 & 460 \\
\hline
\end{tabular}

Liberation of penicillinase from the membrane fraction had the general characteristics of the system shown with intact organisms (Table 5). Thus it was dependent on temperature and $\mathrm{pH}$ value and insensitive to chloramphenicol. Added $\mathrm{Mg}^{2+}$ was not essential but, in some experiments, prolonged the period during which liberation occurred. At $0^{\circ}$ or at $\mathrm{pH} 5.0$ a substantial amount of the enzyme released from the membrane fragments was still in a bound form.

Disruption of the membrane fraction generally led to a severe loss of penicillinasereleasing activity (Table 4). After ultrasonic treatment essentially all of the fragments bearing bound enzyme were small enough to remain in the supernatant fluid after centrifugation for $10 \mathrm{~min}$. at $20,000 \mathrm{~g}$. Very little free enzyme was released during subsequent incubation. Sodium deoxycholate disintegrated the membrane preparations (see Lampen, 1967) and prevented release of free enzyme. (The deoxycholatetreated material did not inhibit release by the untreated preparation.) EDTA, which presumably removed $\mathrm{Mg}^{2+}$ and other cations from the membranes, was also inhibitory. Repeated rapid freezing and thawing did not disperse the membrane preparations to any noticeable degree and had no effect on the rate of release of free penicillinase.

The liberation of penicillinase, although diminished severely, was never abolished 
by disruption of the membranes. Even a purified bound penicillinase preparation, the streptomycin-( $\left(\mathrm{NH}_{4}\right)_{2} \mathrm{SO}_{4}$ precipitate used for Table 4 , still released about $5 \%$ of its enzyme in $24 \mathrm{hr}$ at $30^{\circ}$. After storage for 2 weeks at $5^{\circ}$ about half of the enzyme had been converted to the free form. All bound penicillinase fractions were, therefore, stored at $-20^{\circ}$; they were stable under these conditions for up to one year.

\section{Extracts from uninduced organisms}

With the penicillinase-inducible strain 6346 of Bacillus licheniformis (Pollock, I96I $b$ ), crude extracts of uninduced organisms caused some release of cell-bound penicillinase, but this action could not be separated from cell damage. The availability of purified bound-penicillinase preparations from $B$. licheniformis $749 / \mathrm{C}$ made it possible to measure the formation of free penicillinase directly and without complications from autolytic enzymes released by cell damage. A culture of the penicillinaseinducible wild-type strain 749 of $B$. licheniformis was grown without inducer under the conditions used for the constitutive strain 749/C of B. licheniformis (Lampen, I967). The culture was harvested at a population equiv. to $0.6 \mathrm{mg}$. dry wt organisms (4 units penicillinase)/ml.; at this stage of growth the constitutive strain would be rapidly forming and secreting penicillinase. The organisms were harvested and lysed as described earlier for preparation of the membrane fraction. The culture fluid, the membrane fraction and the cell-extract supernatant fluid were tested (as in Table 4) for ability to form free penicillinase from purified bound enzyme (the streptomycin + $\left(\mathrm{NH}_{4}\right)_{2} \mathrm{SO}_{4}$ precipitate was used at $2000 \mathrm{units} / \mathrm{ml}$. - an amount of bound enzyme present in $0.6-0.8 \mathrm{ml}$. of an induced culture). The membrane fraction was inactive. The extract had a slight effect when present in an amount equivalent to the organisms from $5 \mathrm{ml}$. culture. The undiluted culture fluid released 5-10\% of the enzyme in $3 \mathrm{hr}$ and $25 \%$ in $8 \mathrm{hr}$. This fraction contained detectable quantities of a proteinase (active on casein). Thus all fractions were relatively ineffective in releasing free penicillinase, as compared with the quantities of penicillinase synthesized and released as exoenzyme in an induced culture or by the constitutive strain (approximately $50 \%$ of the bound enzyme liberated/hr). The membrane fraction from the uninduced bacilli might still have contained a system for the liberation of exoenzyme but, if present, it was inactive on added bound penicillinase.

\section{DISCUSSION}

The results presented here, based upon the electrophoretic mobility of the various enzyme forms, emphasize the importance of a test for free (exo-type) enzyme which will differentiate it from enzyme attached to small membrane fragments. The previous criterion (lack of sedimentability in Io min. at $20,000 \mathrm{~g}$ ) did not distinguish between these forms, hence much of what was earlier considered to be release of exopenicillinase actually reflected disintegration of the cell membrane while its bound enzyme remained attached. The mechanism for releasing the membrane-bound enzyme also appears to reside in the membrane. The fraction obtained by lysis and subsequent addition of $\mathrm{Mg}^{2+}$ contained the bulk of the penicillinase-releasing activity. The characteristics of release from the membrane material were very similar to those shown by the intact organisms.

The loss of liberating activity upon distintegration of the membrane preparation may have a variety of explanations. There may be a direct inactivation of the essential 
enzyme(s); this would be analogous to the destruction of the external alkyl- $\beta$-glucosidase of yeast upon rupture of the cell (Kaplan, 1965). It is unlikely that the decrease in activity reflects solely a dilution of the reactants, since both the penicillinase and the residual liberating activity continue to be bound to the particles. More probable is a requirement for a proper steric relationship between bound enzyme and liberating system, to obtain a reasonable reaction rate.

The only evidence about the nature of the enzyme(s) releasing penicillinase is the fact that added proteinase or proteinase-containing extracts or culture fluids (Pollock, $196 \mathrm{r} b$; Lampen, 1967) release free enzyme which is indistinguishable from the natural exoenzyme (Pollock, 1965). The concentration of proteinase in the culture filtrates was too low to account for the normal rate of release of penicillinase; the process in the intact organism was not sensitive to several inhibitors of proteinase action (Pollock, 196I $b$ ). An investigation of the release phenomenon in protoplasts (where possible shielding of the releasing system from inhibitors is minimized) may indicate whether or not a membrane-bound proteinase, properly positioned in relation to the bound penicillinase, is the actual agent.

The findings presented in this and the preceding paper (Lampen, 1967) provide in part the basis for a working hypothesis of the mechanism of penicillinase formation and release (Lampen, 1965), which considers penicillinase formation to be a facet of membrane synthesis. It is suggested that the enzyme is formed as part of a larger unit which is incorporated into new membrane, with the enzyme oriented toward the outside of the permeability barrier and that the bound enzyme is initially in a protected site (membrane invagination?) and becomes susceptible to release once it has become fully external.

The author thanks Dr M. R. Pollock for his hospitality at the National Institute for Medical Research, Mill Hill, London, and to Mr P. Thompson for capable technical assistance. This work was supported in part by grants from the United States Public Health Service (AI-04572) and from the National Science Foundation (GBI I25).

\section{REFERENCES}

Collins, J. F. (1964). The distribution and formation of penicillinase in a bacterial population of Bacillus licheniformis. J. gen. Microbiol. 34, 363.

Halvorson, H., Fry, W. \& SChWEMmin, D. (I955). A study of the properties of the free amino acid pool and enzyme synthesis in yeast. J. gen. Physiol. 38, 549.

KAPLAN, J. G. (1965). An inducible system for the hydrolysis and transport of $\beta$-glucosides in yeast. I. Characteristics of the $\beta$-glucosidase activity of intact and of lysed cells. J. gen. Physiol. 48, 873.

Kushner, D. J. \& Pollock, M. R. (I96I). The location of cell-bound penicillinase in Bacillus subtilis. J. gen. Microbiol. 26, 255.

LAMPEN, J. O. (1965). Secretion of enzymes by micro-organisms. Symp. Soc. gen. Microbiol. I5, II5.

LAMPEN, J. O. (1967). Cell-bound penicillinase of Bacillus licheniformis properties and purification. J. gen. Microbiol. 48, 249.

PoLlock, M. R. (1961 a). The measurements of the liberation of penicillinase from Bacillus subtilis J. gen. Microbiol. 26, 239.

Pollock, M. R. ( $196 \mathrm{I} b)$. The mechanism of liberation of penicillinase from Bacillus subtilis. J. gen. Microbiol. 26, 267.

Pollock, M. R. (1965). Purification and properties of penicillinase from two strains of Bacillus licheniformis: a chemical, physico-chemical and physiological comparison. Biochem. J. 94, 666. 